\title{
Use of Cluster Analysis for Assessment of Surface Replicas Machined by a Laser Beam
}

Milena Kubišová, Vladimír Pata, Libuše Sýkorová, Martina Malachová

Department of Production Engineering, Faculty of Technology, Tomas Bata University in Zlin, Vavreckova 275, Zlin, Czech Republic

This article deals with research of replica preparation of polypropylene surfaces machined by a laser beam. For the production of replicas, we decided to test the material SILOFLEX ${ }^{\odot}$ which is mainly used in dentistry. There we are also looking for expertise in the preparation and application of this material on the surfaces. Subsequently investigated methods of statistical evaluation. In this article the cluster analysis is primarily used, this analysis uses four basic methods: Ward's Minimum Variance, Furthest Neighbour, Weighted Pair-Group and Pair-Weighted Centroid Group. The results are there also demonstrated using Abbott Firestone curves. The result of the article is to demonstrate the similarity of the amplitude of surface roughness parameters using above mentioned four methods Cluster analysis using Cophenetic correlation coefficient and using average values of cumulative totals compiled into the Abbott Firestone curve and the replica of the original surface. Original surfaces and replicas will be scanned using a contactless 3D scanner Talysurf CLI 500.

Keywords: Surface, Replica, Laser, Machining, Polypropylene

\section{Acknowledgement}

This work and the project is realised with the financial support of the internal grant of TBU in Zlin No. IGA/FT/2017/002 funded from the resources of specific university research.

\section{References}

[1] MURALIKRISHNAN, BALA. and J. RAJA. (2009). Computational surface and roundness metrology. New York: Springer, (2009). ISBN 9781848002975.

[2] BILODEAU, M. A., BRENNER D. (1999). Theory of multivariate statistics. New York: Springer, c1999. Springer texts in statistics.

[3] REISS, ROLF-DIETER, THOMAS, M. (2001). Statistical analysis of extreme values: with applications to insurance, finance, hydrology and other fields. 2nd ed. Basel: Birkhäuser Verlag, 2001. ISBN 3-7643-6487-4.

[4] Intelligent Laser System III-NM - Operation Manual, version 1.6.: Laser Tools \& Technics Corp., 2007.

[5] Pentron Clinical. Pentron [online]. Jičín, 2013 [cit. 2017-03-21]. Dostupné z: http://www.pentron.eu/en/products/

[6] BÍLEK, O. (2016). Cutting tool performance in end milling of glass fiber-reinforced polymer composites. Manufacturing Technology - Journal for Science Research and Production [online]. 2016, 16(1), $12-16$ [cit. 2017-0321]. ISSN 12132489.

[7] JINFENG ZHANG, CHAO FENG, YUNHUI MA, WEI TANG, SHUAI WANG, XIN ZHONG. (2017). Nondestructive analysis of surface integrity in turning and grinding operations (2017) Manufacturing Techno$\log y, 17 / 3$, pp. 412-418.

[8] HANZL P., ZETKOVÁ I., MACH J. (2017). Optimization of the Pressure Porous Sample and Its Manufacturability by Selective Laser Melting (2017), Manufacturing Technology, 17/1, pp. 34-38.

[9] HNATKOVA, E., SANETRNIK, D., PATA, V., HAUSNEROVA, B., DVORAK, Z. (2016). Mold Surface Analysis after Injection Molding of Highly Filled Polymeric Compounds. (2016), Manufacturing Technology, 16/1, pp. 86-90.

[10] PODANÝ, J., MOLOTOVNIK, A. (2014). 3D Measurement of Surface Texture Parameters (2014), Manufacturing Technology, 14/4, pp. 596-600. 